\title{
MORAALFILOSOFIESE GRONDSLAE VAN DIE AKSIE VIR PYN EN LYDING
}

\author{
Nic Olivier \\ Departement Romeinse Reg en Regspluralisme \\ Potchefstroomse Universiteit vir Christelike Hoër Onderwys \\ POTCHEFSTROOM
}

\begin{abstract}
It is generally accepted that the two major delictual actions derived from Roman law (the actio legis Aquiliae for patrimonial loss and the actio iniuriarum for sentimental damages in cases of libel) do not provide for the recovery of immaterial damages flowing from injury to the human body. This action for pain and suffering which forms part and pancel of modern South African law has its nooks in other legal systems. This article aims to trace its moral philosphical origins with neference to the views of Thomas of Aquino, authors of manuals used during confession and the sizreenthcentury Spanish philosophers, as well as their influence on the important Roman-Dutch outhor, Hugo de Graot. In this conteat the role of restitution as instance of iustitia commulativa is pivolal.
\end{abstract}

\section{INLEIDING}

Die aksie weens die nalatige veroorsaking van pyn en lyding vind in die huidige Suid Afrikaanse reg uitgebreide toepassing1. Daarmee word vergoeding vir immateriële nadeel (persoonlikheidsnadeel) voortvloeiend uit die aantasting van die menslike liggaam (corpus of psigies-fisiese integriteit) verhaal. Die vernaamste skadeposte (uitgekristalliseerde verskyningsvorme) waarkragtens (weens die toename in veral motorongelukke) genoegdoening verhaal word, is pyn en lyding, ontsiering, verlies var, lewensgenietinge, verlies van gesondheid, verkorte lewensverwagting en senuskok. Dic Romeinse reg het ' $n$ verbod op die vergoeding van immateriële nadeel in die geval vair besering van vry mense geplaas. ${ }^{2}$ Die ratio vir dié benadering was geleè in die siening dat die liggaam van vry mense nie op geld waardeerbaar is nie ${ }^{3}$. Die aksie weens pyi

\footnotetext{
${ }^{1}$ Kyk oor die aksie weens pyn en lyding Boberg, Law of Delict 516-530; Olivier, Die aksie weens die nalatige veroorsaking van pyn en byding. Van der Merwe \& Olivier, Die onregmatige daad in die Suid-Afrikeanse reg 242-249; Van der Walt, Delict 108-109 asook die literatuur deur outeurs vermeld.

${ }^{2}$ D 9.1.3; D 9.3.7. Kyk daaroor Olivier, Pyn en byding 20-36.

${ }^{3}$ D 9.1.3; D 9.3.7: "Liberum corpus non recipit aestimationem"
} 
en lyding bestaan naas die twee hoof deliktuele aksies wat Romeinsregtelik van oorsprong is, naamlik die actio legis Aquiliae en die actio iniuriarum. Met eersgenoemde word skadevergoeding vir onregmatig skuldig veroorsaakte vermoënskade (byvoorbeeld mediese uitgawes en verlies van inkomste voortvloeiend uit 'n motorongeluk) geëis. Die actio iniurianum daarenteen, word aangewend om genoegdoening weens opsetlik veroorsaakte persoonlikheidskrenking (byvoorbeeld laster) te verhaal.

Die oorsprong van die aksie weens pyn en lyding is dus nie in die Romeinse reg geleë nie. Die Suid-Afrikaanse regspraak gaan van die standpunt uit dat die aksie slegs Germaansregtelike wortels het ${ }^{4}$.

Hierdie artikel het ten doel om die inhoud en invloed van een van die ontstaansbronne van die aksie weens pyn en lyding te ondersoek ${ }^{5}$. Die moraalfilosofiese grondslae hiervan word aan die hand van die beskouings van Thomas van Aquino en sy tydgenote, die Middeleeuse biegpraktyk, die sestiende-eeuse Spaanse laat-Skolastici (die Spaanse moraalfilosowe) asook hul invloed op Hugo de Groot beskryf. De Groot word allerweë beskou as een van die vernaamste Romeins-Hollandse outeurs - wie se standpunte (ook ten aansien van die onderhawige aksie)deur latere skrywers gevolg is ${ }^{6}$. Daar sal aangetoon word dat die aksie weens pyn en lyding vanweë sy eiesoortige historiese grondslae en sy besondere doelstelling (die vergoeding van immaterielle nadeel voortvloeiend uit die aantasting van die menslike fisies-psigiese integriteit (corpus)) ook in die moderne Suid-Afrikaanse reg 'n eie staanplek naas die twee hoof deliktuele aksies het. Op generlei wyse kan dié aksie deur die actio legis Aquiliae of die actio iniuriarum (elk met sy eie teoretiese begronding, aanwendingsgebied en doelstelling) ondervang word nie.

\footnotetext{
4 Vgl. byvoorbeeld Hoffa v SA Mutual and Fire Insurance 19652 SA 944 (K) 951E; Bester y Commercial Union Versekeringsmaatskappy, 19731 SA 769 (A) 776D. Vgl. ook Olivier, Pyn en lyding 234-242. Van der Merwe \& Olivier, Onregmatige daad 15 is van mening dat die aksie Germaansregtelik van oorsprong is; Boberg, Law of Delict 517 en Van der Walt, Delict 17 in 4 sien die oorsprong in die Germaanse reg en die natuurreg.

${ }^{5} \mathrm{Kyk}$ Olivier, Pyn en lyding 1-178 vir 'n bespreking van die verskillende ontstaansbronne en hul onderlinge samehang.

${ }^{6}$ Kyk ook Olivier, Pyn en lyding 83-110 135-138. Vgl. Van Zyl, Geskiedenis van die RomeinsHollandse Reg 346-352 t.a.v. De Groot se werke en invloed.
} 


\section{AGTERGROND}

Daar word vandag algemeen aanvaar dat die belangrike Romeins-Hollandse juris, Hugo De Groot (1583-1645) sterk onder-die invloed van die Spaanse laat-Skolastici (hoofsaaklik van die sestiende eeu) gestaan het 7 . Nie net ten aansien van materiële regskwessies nie, maar ook ten aansien van die natuurregtelike uitgangspunte het daar 'n duidelike aantoonbare band tussen hierdie groep outeurs en De Groot ontstaan. In sy De iure belli ac pacis - 'n natuurregtelike werk wat die grondslag van die moderne volkereg vorm - kom daar verwysings na hierdie outeurs voor.

Die Spaanse laat-Skolastici van die sestiende eeu het voortgebou op die tradisie van Thomas van Aquino (1225-1274) ${ }^{8}$ en het sy restitusieleer (as onderdeel van sy geregtigheidsbeskouing) oorgeneem. (De Groot verwys ook self na Thomas in hierdie verband.) Hulle werk moet ook gesien word in die lig van die laat-Middeleeuse biegpraktyk waarkragtens individuele lidmate verplig was om op 'n gereelde grondslag te bieg. Die biegvader (confessor - 'n priester) het die betrokke bieglidmaat beveel om self die versteurde verhouding met sy medemens reg te stel. Die biegpraktyk is beskou as 'n derde jurisdiksie (naas dié van die gewone howe en die kerklike howe) - die forum conscientiae (forum internum) ${ }^{9}$. Die invloed van bieghandleidings in die afdwinging van die restitusieplig is duidelik aantoonbaar. Die werke van die sestiende-eeuse Spaanse laat-Skolastici was ook in 'n hoẻ mate gerig op die toepassing van die moraalfilosofie binne die biegpraktyk.

\footnotetext{
7 Vgl. byvoorbeeld Feenstra, Théories sur la responsabilite civile en cas d'homicide et cn cas de lésion corporelle avant Grotius en droit prive", Etudes d'histoire du droit privé oftertes á Picrre Petat 157-171; 'L'Influence de la Scholastique espagnol sur Grotius en droit privt: quelques experiences dans des questions de fond et de forme, concernant notamment les doctrines de l'erreur et de l'enrichissement sans cause," La Seconda Scolastica nella formazione del diritto moderno. Incontro di studio. Firenze. 16-19 oltobre 1972. Atti 377 e.v. en dis: gesag daar aangehaal (ook in Feenstra, Fata luris Romani 388 c.v.). Kyt ook Wieacker, Privatrechtseschichte der Neuzeir 287 e.v.; Thieme 1953 ZSS (GA) 70:230, 262 e.v.; Thieme, Das Naturnecht und die europdische Privatrechtsgeschichte 19 c.v.; Welzel, Naturrecht und materielle Genechtigkeit 123 c.v.; Nufer, Uber die Restitutionslehre der spanischen Spdtscholastiker und ihre Ausstrahing auf die Folgezeit 70 e.v, asook die ander artikels in La Seconda Scolastica.

${ }^{8} \mathrm{Vgl}$. Nufer, Spalscholastiker 64-(66 en dic literatuur daar vermeld.

9 Kyk hieroor Glorieux, "Sommes", Dictionnaire de Théologie Catholique XIV 2 col. 2350 c.v.; Le Bras, "Pentitentiels", Dictionnaine de Theol'gie Catholique XII 1 col. 1160 e.v.; Trusen, Anfange des gelehren Rechts in Deutschland - Ein Beitrog zur Geschichte der Fnihrezeption. Trusen 197 ZSS(KA) 88:83-126, Michád-Quantin, Somme de casuistique et manuels de confession al moyen age (XII-XVI siecles). Vir 'n deeglike oorsig vgl. Bergfeld, "Kathotische Moraltheologie und Naturrechtslebre", in Coing (red) Handbuch der Quellen und Literatur der neueren Privatrechtsgeschichte 11/1, 999-1034 999-10.5.
} 
Die moraalfilosofie was ' $n$ onderdeel van die teologie reeds vanaf die Konsilie van Nicea (325). ${ }^{10}$ Die opvatting het posgevat dat daar gedragsnorme ooreenkomstig die Christelike moraal neergele moet word wat as 'n etiese minimum moes dien. Hierdie benadering het veral in die werk van Augustinus (345-430) sterk na vore gekom; Platoniese denkbeelde word daarin versoen met die Christelike moraal11. In die Middeleeue het die bestudering van die moraalfilosofie weens die groot gesag van Petrus Lombardus se Libri quattuor Sententiarum van 1150 , die opkoms van die biegpraktyk en die toenemende invloed van die Skolastiek (gegrondves deur Anselmus van Canterbury (+1109)) met sy hernieude belangstelling in die klassieke filosofie, 'n sterk stoot vorentoe gekry 12 .

In die laat-Middeleeue het die kanonieke reg 'n groot invloed op die profane reg gehad13. Die rede hiervoor is geleë in die feit dat die kerklike howe oor die bevoegdheid beskik het om wêreldlike sake (causa seculares) te beoordeel; en dié bevoegdheid het ratione peccati bestaan, waar peccatum gelyk gestel is aan 'n sondige handeling 14 . Die beinvloeding van die wêreldlike howe deur die kanonieke reg en van die fora externa na die profane ius civile het aanleiding gegee tot 'n wedersydse subsidiariteitsbeginsel wat neerslag gevind het in die volgende spreuk:

Ius canonicum et civile sunt adeo connexa, ut unum sine altero non intellegi potest. ${ }^{15}$

\footnotetext{
${ }^{10}$ Mausbach-Ermecke, Katholische Moraltheologie I. Band 50.

"I Mausbach-Ermecke, Katholische Moraltheologie 51.

${ }^{12}$ Mausbach-Ermecke, Katholische Moraltheologie 51-52. Kyk ook Schilling, Die Staats- und Soziallehre des HI. Thomas von Aquin 20-26.
}

${ }^{13}$ Kyk bv. Norr, "Die kanonistiese Literatur", Handbuch 1365 e.v. cn die gesag daar aangehaal en Wieacker, Privatrechtsgeschichte $76 \mathrm{en}$ die gesag daar aangehaal.

${ }^{14} \mathrm{Kragtens}$ X 2.1.13 kon die geestelike gerig sub peccati praetertu elke saak per denuntiationem evangelicam verhoor, veral waar die handelinge ratione periurii vel pacis fractae geskied het. Insgelyks was die forum extemum bevoeg in aangeleenthede waar die iustitia commutativa geskend is - Trusen, "Die gelehrte Gerichtsbarkeil der Kirche", in Coing (red) Handbuch der Quellen und der Lileratur der neueren europdischen Privatrechtsgeschichte I 486 en vgl. ook Scott, Die geskiedenis van die oorerflikheid van aksies op grond van onregmatige daad in die SuidAfrikaanse reg 53-54.

15 Aangehaal deur Wieacker, Privatrechtsgeschichle 97. Dit impliseer egter nie dat die kerklike hof slegs jurisdiksie gehad het waar die wêreldlike hof nie opgetree het nie. 'n Leek kon egter nie teen sy wil gedwing word om voor die kerklike regbank (buiten in die gevalle waar dit voorgeskryf was) te voorskyn nie: ..."nisi in defectu iustitiae secularis vel nisi consuetudo id exposcat" (die latere summarium op X 2.2.10). Vgl. verder Trusen, Die gelehme Gerichusbarkeit 485-487. 
Wat die verband tussen die moraalfilosofie en die kanonieke reg betref, kan daar aanvaar word dat dit in 'n noue verbintenis langs mekaar bestaan het en dat daar sprake van wisselwerking was ${ }^{16}$. Die rol van die moraalfilosofiese aquitas christiana (Christelike billikheid) in dié verband was besonder groot ${ }^{17}$. Aan die ander kant moet daar in gedagte gehou word dat die objek verskillend was: by die moraalfilosofie het dit gegaan om 'n regsorde in conscientia te vestig terwyl die kanonieke reg veel meer daarop gerig was om 'n alternatiewe openbare regsorde te skep.

Ten aansien van die verhouding met die wêreldlike reg was daar ook sprake van 'n wisselwerking. Veral die latere moraalfilosowe betrek Romeinsregtelike norme in hul werke. Die regsorde in conscientia het verder weer invloed uitgeoefen op die regsopvatting van die individu en sodoende van die gemeenskap ${ }^{18}$.

\section{THOMAS VAN AQUINO EN SY TYDGENOTE}

Thomas van Aquino (1225-1274) was volgens Welzel die belangrikste Middeleeuse moraalfilosoof ${ }^{19}$. In die tweede deel van sy Summa Theologica (1265-1273) behandel Thomas die moraalfilosofie. Hy vorm die knooppunt tussen die Christelike moraal en Stoïsyns-Aristoteliaanse intellektualisme. In sy natuurregsisteem neem die deug (virtus) 20 met sy verskyningsvorme: prudentia (wysheid, insig), fortitudo (dapperheid), temperantia (gematigdheid) en iustitia (geregtigheid) 'n sentrale plek in. Thomas se beskouings oor geregtigheid kom in die afdeling "De iustitia et iure" (Quaestiones 57-59 van die tweede gedeelte, die Secunda Secundae) van sy Summa Theologica voor. Sy geregtigheidsiening is gebaseer op Aristoteles se uiteensetting 21 . In hierdie verband is

\footnotetext{
${ }^{16} \mathrm{Vgl}$. Nufer, Spätscholastiker 60-63.

${ }^{17}$ Bergfeld, Moraltheologie 999.

${ }^{18} \mathrm{Vgl}$. Nufer, Spätscholastiker 66-68 en Bergfeld, Moraltheologie 1018

${ }^{19}$ Kyk Welzel, Naturrecht 60 e.v. vir 'n oorsig van Thomas se natuurregleer.

${ }^{20} \mathrm{Dit}$ is die sg. virtutes cardinales (primêre deugde). Die term is afkomstig van Ambrosius, De Sacramentis 3.2.8; vgl. Mausbach-Ermecke, Moraltheologie 293.

${ }^{21}$ Ethica Nikomacheia 5.9.10. Kyk verder hieroor Thomas Secunda Secundae 58.5. Iustitia commutativa (vergeldende geregtıgheid) vorm saam met die iustitia distributiva (verdelende geregtigheid) die iustitia particularis wat die individuele of besondere geregtigheid daarstel. Daartcenoor staan die iustitia legalis (generalis) (gemeenskaplike geregtigheid) wat dic verhouding van die individu teenoor die gemeenskap (relatio partis ad torum) beheers.
} 
sy siening van iustitia commutativa 22 van besondere belang. Iustitia commutativa as vergeldende geregtigheid reël die verhouding tussen individue onderling (relatio partis ad partem) ${ }^{23}$ Wanneer dit versteur word ${ }^{24}$, vereis aequalitas (ewewig, gelykheid ${ }^{25}$ ) dat die vorige toestand by wyse van restitutio herstel moet word ${ }^{26}$. Die nalewing van geregtigheid as kardinaaldeug hou in dat in die geval van ongeregtigheid (iniustitia) dit vir die sieleheil (salus) noodsaaklik is dat restitusie (restitutio) moet plaasvind ${ }^{27}$; restitusie word sodoende gesien as actus iustitiae commutativae 28 .

In gevalle van vermoënskade (damnum in rebus exterioribus; damnum of detrimentum temporale $)^{29}$ moet restitusie plaasvind deur teruggawe van die saak. Waar dit nie moontlik is nie, moet restitusie op gelykwaardige wyse (recompensatio aequivalens) geskied $^{30}$. Restitusie moet volgens Thomas ook plaasvind waar nie-vermoënsgoedere aangetas is 31 . Aangesien 'n recompensatio aequivalens onmoontlik is, moet daar 'n andersoortige restitusie 32 (wat by wyse van of 'n aliquis honor of geld kon geskied) 33 plaasvind. Die maatstaf hier is die lewensomstandighede van elke persoon volgens die oordeel van 'n wyse man ${ }^{34}$. As voorbeeld van aantastings van aangeleenthede wat tans

\footnotetext{
${ }^{22}$ Secunda Secundae 58.12 ad primum.

${ }^{23}$ Secunda Secundae 58.12 ad primum.

${ }^{24}$ Vgl. Mausbach-Ermecke, Monaltheologie 532-533 en Nufer, Spatscholastiker 11.

${ }^{25}$ Dit gaan hier om die gelykheid tussen twee reghebbendes.

${ }^{26}$ Secunda Secundae 62.1 resp.

${ }^{27}$ Secunda Secundae 62.2 resp

${ }^{28}$ Secunda Secundae 62.1 resp

${ }^{29}$ Secunda Secundae 62.1 ad secundum.

${ }^{30}$ Secunda Secundae 62.1 resp; 62.2 ad primum.

${ }^{31}$ Secunda Secundae 62.1 ad secundum.

${ }^{32}$ Secunda Secundae 62.2 ad primum met verwysing na Ethica Nikomachela 8.16

${ }^{33}$ Secunda Secundae 62.1 ad secundum

${ }^{34}$ Secunda Secundae 62.2 ad primum en 62.2 ad quartum.
} 
as nie-vermoënsgoedere of persoonlikheidsgoedere aangemerk word, noem hy die aantasting van die eer, die goeie naam, die liggaam en die lewe ${ }^{35}$. As verdere voorbeeld noem hy die verwydering van 'n ledemaat ${ }^{36}$.

Sy aanvaarding van die standpunt dat immateriële nadeel voortvloeiend uit 'n besering vergoed moet word, het groot invloed op die latere Spaanse moraalfilosowe uitgeoefen.

In navolging van Bonaventura (+1274) - 'n tydgenoot van Thomas wat egter voortgebou het op die Augustynse tradisie - het Johannes Duns Scotus (1270-1308) die Augustynse denkbeelde probeer herstel 37 . Hy verwerp die Thomistiese navolging van die Stoïsyns-Aristoteliaanse intellektualisme en leer dat voluntas imperat intellectui ${ }^{38}$.

In sy Quaestiones in librum quartum Sententiarum bespreek hy die vraag of nadeel anders as vermoënskade wat aan 'n persoon toegebring is, ageerbaar is. As basis vir sy afwysende antwoord aanvaar hy dat niemand aan die prestasie van die onmoontlike gebonde is nie 39 .

Hy argumenteer dat in sake van die persoonlikheid (byvoorbeeld die liggaam) restitusie onmoontlik is, aangesien daar nie sprake is van bona exteriora (sake buite die mens geleë) nie 40 . Mediese uitgawes en verlies aan inkomste behoort egter wel vergoed te word; dit is bona exteriora.

\footnotetext{
${ }^{35}$ Kyk Mausbach-Ermecke, Moraltheologie Band III 542; Pauw, Persoonlikheidskrenking 59.

${ }^{36}$ Kyk Secunda Secundae 62.2 ad secundum: "Puta, cum aliquis alicui abstulit membrum, debet ci recompensare vel in pecunia vel in aliquo honore, considerata conditione utriusque personae, secundum arbitrium probi viri". Kyk ook vn 32

37 Welzel, Natumecht 71.

${ }^{38}$ Ou. 4. d. 49 qu. 4 q. ax lat. n. 16 soos aangehaal deur Welzel, Neturrecht 71. Hy word beskou as die vader van die voluntarisme - "die Akle der Vernunft sind fïr den Willen nur conditiones sine quibus non, nicht conditiones per quas" (Welzel, Naturnecht 70).

39Johannes Duns Scotus: in Opera Omnia (anastatiese herdruk van die Lyon 1539-uitgawe), Band 9, Liber IX, Distinctio 15, Quaestio III, Art. 1 ( = Sententiae 4.15.3.1): "Utrum damnificans alium in bonis personac, scilicet corporis vel animae, tencatur restituere ad hoc, quod possit vere poenitere" - met 'n berocp op Augustinus Retroctationes 1.9.

${ }^{40} \mathrm{Hy}$ voer die volgende argumente in sy Sententiae 4.15.3.2 aan:

(a) Decretum Gratiani C.6 q.1 c.9;

(b) Exodus 22 (in die geval van seduksie moet daar naas die dos 'n addisionele bedrag betaal word, en moet daar ook met die betrokke vrou getrou word);

(c) X 5.36.1 en Exodus 21.18-19.
} 
Scotus onderskei verder tussen mutilatio (skending) en vulneratio vel alia laesio curabilis (verwonding of ander herstelbare besering). 'n Mutilatio kan of enormis of non enormis wees; die bepalende faktor is of sodanige mutilatio actum humanum ex tot impedit (menslike handelinge aan bande le $)^{41}$. Hy wys vervolgens daarop dat die lex talionis (weerwraak) in geval van ' $n$ mutilatio geld omdat ' $n$ recompensatio aequalis nie bestaan nie $e^{42}$.

Buiten hierdie talio-aanspreeklikheid bestaan daar ook 'n restitusieplig vir mediese uitgawes en verlies aan inkomste soos neergelê in die Liber Extra ${ }^{43}$. Hy konkludeer egter dat daar ook 'n placatio laesi (salwing van die benadeelde) of consolatio ipsius afflicti (troos vir die verwonde self) - mits die benadeelde dit versoek - by wyse van geld betaal moet word. Dit behoort veral in die geval van die skending of misvorming van 'n arme (mutilatio pauperis) te geskied 44 , aangesien die misvormde of verwyderde ledemaat gebruik is vir die verkryging van noodsaaklike lewensmiddele. Die geskende bona corporis kan dus met ooreenkomstige bona exteriora vergoed word ${ }^{45}$.

\section{HANDLEIDINGS VIR DIE BIEGPRAKTYK}

Vervolgens moet die standpunt van die handleidings vir die biegpraktyk onder die soeklig geplaas word. Op die vierde Lateraanse Konsilie van 1215 is daar aanvaar dat lidmate ten minste een keer per jaar voor 'n priester moes gaan bieg. Dié biegvader moes die persoon se skuld aan die hand van die omstandighede (circumstantiae) bepaal en 'n oordeel oor die aan hom voorgedraagde gewetensvrae (casus conscientiae) uitspreek, en sodoende het daar 'n behoefte aan bieghandleidings ontstaan ${ }^{46}$. Hierdie

\footnotetext{
${ }^{41}$ Sententiae 4.15.3.4.

42 Sententiae 4.15.3.4 \& de primo. Hy beklemtoon die feit dat dit nie die Mosaise regsreél as sodanig is wat hier toegepas word nie, maar dat dit of kanoniekregtelike reels is wat deur die Pous ingevoer is (vgl. X 5.36.1) df regsrečls wat deur die keiser neergele is.

${ }^{43} \mathrm{X}$ 5.36.1: "Si rixati fuerint homines, et percusserit alter proximum suum lapide vel pugno, et ille mortuus non fuerit, sed iacuerit in lecto, qui percusserit, operas eius et impensas in medicos restituat."

${ }^{44}$ Sententiae 4.15.3.9 met verwysing a $X$ 5.36.7. Kyk ook Feenstra, La Responsabilite civile avant Grotius 160.

${ }^{45} \mathrm{Vgl}$. Sententiae 4.15.3.10.

${ }^{46}$ Kyk Bergfeld, Moraltheologie 1000 .
} 
uitspreek, en sodoende het daar 'n behoefte aan bieghandleidings ontstaan ${ }^{46}$. Hierdie Summae confessorum (Summae conscientiae of Summae casuum) het voorskrifte bevat waarin regs- sowel as moraalnorme opgeneem is. Die eerste belangrike samevatting was die Summa de casibus poenitentiae van Raymundus de Penaforte (ca.1185-1275) ${ }^{47}$.

Ongeveer twee eeue later (in die laat 15e-eeu) het daar twee belangrike Summae verskyn wat gereeld deur die latere sestiende-eeuse Spaanse moraalfilosowe aangehaal is. In die Summa Angelica (Angelus Claretus de Clavasio (+ca. 1495) se Summa de casibus conscientiae, 'n werk wat vir juridies geskoolde confessores bedoel was) ${ }^{48}$, kom die standpunt voor dat mediese uitgawes sowel as alle reeds gelede en toekomstige verlies van inkomste in die geval van verwonding vergoed moet word. In die geval van 'n onherstelbare verwonding (byvoorbeeld die verlies van 'n ledemaat of 'n permanente skending) moet daar 'n tipe genoegdoening (placatio lesi) betaal word 49 . $\mathrm{Na}$ analogie van die reêling by doodslag is die maatstaf vir die bepaling van die omvang van die damnum (mediese uitgawes en die verlies aan inkomste) en die salwing van die verwonde persoon (placatio lesi) sy persoonlike omstandighede en stand (qualitas personue) met inagneming van die boni mores soos bepaal deur 'n probus vir50.

Die Summa Summarum casuum conscientiae seu Silvestrina het as samevattende handleiding alle vroeëre Summae verdring. Die opsteller, Silvester de Prierio $(+1523)$, het van 'n groot hoeveelheid outeurs gebruik gemaak: 48 teoloe,, 18 summiste en 113 juriste ${ }^{51}$. Met verwysing na Thomas, Scotus en Angelus wys hy daarop dat nie net mediese uitgawes en verlore inkomste (reeds gelede en toekomstige) in die geval van verwonding geëis kan word nie, maar dat daar in die geval van 'n laesio incurabilis (onherstelbare verwonding) ook 'n placatio lesi moet plaasvind52. Placatio lesi kom neer op 'n versoening van die benadeling; dit geskied by wyse van 'n terugbetaling. Silvester erken dus die beginsel dat daar in die geval van blywende skending (laesio incurabilis)

\footnotetext{
${ }^{46}$ Kyk Bergfeld, Moraltheologie 1000.

${ }^{47} \mathrm{Vgl}$. Michaud-Quantin, Somme 26 e.v.

${ }^{48}$ Bergfeld, Moraltheologie 1004.

${ }^{49}$ Restitutio i.ii (fol. 225ra-rb).

${ }^{50}$ Summe Angelica s.v. Restitutio i.ii. Vgl. verder die trefwoord homicidium (s.v. Homicidium v.6) waar hy die begrip mutilatio omskryf.

${ }^{51}$ Vgl. Michaud-Quantin, Somme 101 e.v. en kyk Bergfeld, Moraltheologie 1005.

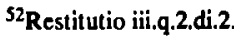


'n restitusieplig bestaan.

\section{LAAT-SKOLASTICI}

In die begin van die sestiende eeu het daar 'n nuwe rigting in die moraalfilosofiese publikasies na vore gekom; naamlik die kommentariëring van Thomas se Summa Theologica. Die eerste belangrike eksponeut hiervan was die kardinaal Thomas de Vio Caietanus (1469-1534) wat in sy Summa Theologica53 Thomas van Aquino se omskrywing van restitutio (as actus iustitiae commutativae) aanvaar ${ }^{54}$. Waar 'n restitutio sui (restitusie by wyse van 'n soortgelyke saak) onmoontlik is, moet daar 'n recompensatio aequalis (gelykwaardige rekompensasie) plaasvind55. Dié reel vind ook toepassing by immateriële nadeel voortvloeiend uit ' $n$ besering.

Hierdie belangstelling in Thomas van Aquino se natuurreg- en restitusieleer was 'n kenmerk van die reaksie in die sestiende eeu teen die nominalisme. Die nominalisme ${ }^{56}$ - wat die bestaan van universalia verwerp het - was 'n logiese uitvloeisel van die voluntaristiese beskouings van Duns Scotus, en is verteenwoordig deur Wilhelm Ockham (1290-1349), Petrus d'Ailly (1350-1420), Johannes Gerson (1363-1429) en Gabriel Biel $(+1495)$.

Hierdie reaksie teen die nominalisme het sy hoogtepunt in Spanje gehad57. Een van die belangrikste redes hiervoor was dat die grondlegger van die Spaanse moraalfilosowe, Francisco de Vitoria (1492-1546), aan die Dominikaanse kollege Saint Jaques in Parys studeer het. Sy leermeester, Pierre Crockaert, het in 1509 die Sententiae van Petrus Lombardus - wat tot op daardie stadium die leerboek vir moraalfilosofie was vervang met die Summa Theologica van Thomas van Aquino 58

Die Universiteit van Salamanca het in die vyftiende en sestiende eeu as sentrum vir teologiese en juridiese studies 'n hoë aansien dwarsoor Europa geniet ${ }^{59}$. Die uitgangs-

\footnotetext{
${ }^{53}$ (Trier 1581)

${ }^{54}$ Summa Theologica ad Secundam Secundae 62.1.

SS Summa Theologica ad Secundam Secundae 62.2. ad primum.

S6-die einflussreichste philosophische Richtung des ausgehenden Mittelalters" - Welzel, Netumecht 81.

57Welzel, Natumecht 81.

S8Bergfeld, Monatheologie 1016.

${ }^{59}$ Dit was gedurende die sogenaamde Goue Eeu van Spanje (Siglo d'Oro); Villey, La Formation
} 
punt van die dosente aldaar was die moraalteologiese natuurreg60; hulle het benewens algemene beskouings oor die natuurreg ${ }^{61}$, ook gepoog om norme (natuurlik binne die Christelike moraalfilosofie) vir die daaglikse lewe neer te lè. Die Summa Theologica van Thomas het die onderwysstof gevorm; en daar is veral aandag geskenk aan die gedeelte De iustitia et iure ${ }^{62}$. In die werksaamhede van hierdie skool (ook bekend as die Spaanse laat-Skolastici, moraalfilosowe of natuurreggeleerdes) is die uitgangspunte van die Skolastiek duidelik te bemerk. Net soos hulle voorgangers aanvaar hulle auctoritas en ratio as koordinate ${ }^{63}$.

Uitgaande van die vier kardinaaldeugde word iustitia as sluitsteen (potissima moralium virtu(um) aanvaar. Restitusie is as actus iustitiae commutativae omskryf64. Ten aansien van die vraag of daar in die geval van aantasting van persoonlikheidsgoedere restitusie moet plaasvind, word daar onderskei tussen vermoënskade (damnum in bonis externis, detrimentum temporale) en immateriële skade (damnum vitae, damnum corporis) ${ }^{65}$.

Hoewel die nominalistiese invloed nog in Vitoria ${ }^{66}$ se werk sigbaar is, verwys hy onder

de la Pensé juridique modeme 357 wys daarop dat daar gedurende hierdie tydperk ongeveer 60 dosente jaarliks onderrig aan 6000-7000 studente verskaf het. Kyk ook Reibstein, Johannes Althusius als Fortsetzer der Schule von Salamanca 23 e.v. en Krause, Naturrechller des sechzehnten Jahrhunderts 33 e.v.

${ }^{60}$ Reibstein, Althusius 24-25 toon aan dat daar drie strominge (die konsilięre beweging die via moderna van die Skolastiek en die filosofiese Humanisme) in Europa voorgekom het wat 'n invloed op die Spaanse natuurregskrywers uitgeoefen het; dit het uiteindelik op die vernuwing van regsdenke en die uitbouing van 'n profane natuurreg uitgeloop.

${ }^{61}$ Vir 'n duidelike samevalting vgl. Bergfeld, Moraltheologie 1018.

${ }^{62}$ Quacstiones 57-79 van die tweede deel van die tweede boek, die Secunda Secundae. Vgl. Bergfeld, Moraltheologie 1017.

${ }^{63}$ Die belangrikste outoriteite was die Heilige Skrif, Aristoteles, die kerkvaders en Thomas. Vgl. die volgende opmerking van Wieacker, Privatrechtsgeschichle 251: "... die Aufgabe der Vernunft war damals nicht die kritik der vorgegebenen Autoritäten, sondern ihr unablăssige Bewahrheitung durch die Auslegung der Texte." Kyk verder Nufer, Spatscholastiker 10 en vgl. Welzel, Naturrecht 94 e.v.

${ }^{64}$ Kyk bv. Vitoria, Summa Theologica ad Secundam Secundae 62.1, nr. 1; Molina, De iustitia et iure 2.714-715. Sien verder Nufer, Spätscholastiker 12-13.

${ }^{6}$ Vgl. Nufer, Spdescholastiker 57.

${ }^{66}$ Vir 'n volledige oorsig oor Vitoria se lewe en privaatregtelike bydrae vergelyk Otte, Das Privatrechr bei Francisco de Vitoria en die literatuur daar vermeld. Vitoria se Summa Theologica was tot die verskyning daarvan in 1934 (uitgawe van Beltram de Heredia, Madrid) slegs in manuskripvorm bekend. Kyk verder bv. Reibstein, Althusius 28-29; Thieme, Natilliches 
beeld dié van Petrus de Palude en Thomas de Vio Caietanus) ${ }^{67}$, die Summa Sylvestrina ${ }^{68}$ asook bepaalde kanoniste soos Panormitanus $(+1445)^{69}$. Hy het 'n groot invloed op meeste latere Spaanse moraalfilosowe en ook indirek op Grotius uitgeoefen 70 . Die Dominikaanse geleerde wat ook in die totstandkoming van die moderne volkereg 'n groot rol gespeel het' 71 , het moraalteologie aan die Universiteit van Salamanca gedoseer. Sy voorlesings op Thomas se Secunda Secundae is eers na sy dood gepubliseer.

In die geval van verwonding moet volgens Vitoria sowel die mediese uitgawes as die verlies aan inkomste (reeds gelede en toekomstige) vergoed word72. Die verlies aan toekomstige inkomste moes bepaal word secundum arbitrium boni viri73. Wat die vergoeding van immateriěle nadeel (byvoorbeeld die ontneming van 'n oog, gebruiksaantasting van 'n ledemaat of die afsny van 'n hand (oculum ervatur, membrum impeditur, manus abscissio)) betref, verwys 74 hy enersyds na die bevestigende houding van onder andere Thomas 75 , Petrus de Palude ${ }^{76}$, Hadrianus ${ }^{7}$ en Scolus ${ }^{78}$ en andersyds

Privatrecht und Spdescholassik 237-243.

${ }^{67}$ Afdeling 3 hierbo.

${ }^{68}$ Afdeling 4 hierbo.

${ }^{69}$ Otte, Vitoria 32-38 gee 'n volledige corsig van bronne deur Vitoria geraadpleeg.

70Otte, Vitoria 133-146.

${ }^{71}$ Kyk byvoorbeeld die literatuur vermeld deur Otte, Vioria 4 a 17.

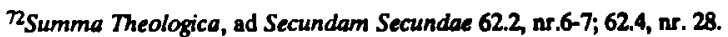

${ }^{73}$ Summa Theologica, ad Secundam Secundoe 62.2, ar.10.

${ }^{74}$ Summa Theologica, ad Secundam Secundae 62.2 ar. 8.

${ }^{75}$ Secunde Secundae 62.2.

${ }^{76}$ In quartum Sententiarum (Venesié 1493), dist. 15 qu. 2 art. 2. concl. 2 (4 hierbo).

${ }^{7}$ Dic latere Pous; in sy Quaestiones in quartum Sententiarum proesertim circa sacramenta (1518) verklaar hy na aanleiding van die afwysende standpunt van kanoniste (skrywers oor die kanonieke reg) soos Duranti (+ 1296; in sy hoofwerk oor die Middeleeuse prosesreg, Speculum Iudiciale (1539) 4.2.2.3), Johannes Andreae (In quintum Decretalium librum novella commenotria (1581) ad X 5.36.1, nr, 1-7; ad X 5.39.13, nr. 4; ad X 5.39.22, nr. 1) cn Panormitanus (Nicolaus de Tudeschis $(+1445)$ Commentaria ad X 5.36.1) dat 'n eis weens ontsiering in beginsel volgens die positiewe reg ontoelaatbaar is maar wel kragtens die natuurreg toegestaan behoort te word (quaestio 36). Hier kan ook nog verwys word na die standpuni van Richardus de Mediavilla, Super quarto libro Sententianm (ca. 1478)) dat dic 
na die ontkennende houding van Johannes Maior79. Vitoria beskou dié nadeel as 'n iniuria, en gaan van die standpunt uit dat daar restitusie in bonis temporalibus (by wyse van geld) moet plaasvind:

Et in hoc etiam debet restituere injuriam factam, ratione injuriac naturalis factac. Et dato quod iste nihil lucretur, vel parum amisserit, tamen ratione injuriac factae debet ci fieri recompensatio. Unde non solum debet solvere expensas et sumptum cum medico et chirurgico, si fuit laesus, sed etiam infirmo debet fieri recompensatio, ita quod injuriae est facienda recompensatio ${ }^{80}$.

Net soos Thomas van Aquino ${ }^{81}$ aanvaar hy dat die grondslag gelykheid (aequalitas) is, en meld hy dat die maatstaf vir die bepaling van die omvang van die genoegdoening betaalbaar vir die skending die oordeel van 'n bonus vir is ${ }^{82}$. Hy verwerp die standpunt dat die benadeelde self by die bepaling van die quantum van die immateriële nadeel (aestimatio iniuriae)' $n$ rol behoort te speel ${ }^{83}$.

Martinus Azpilcueta (1493-1586; ook bekend as Doctor Navarrus) het as moralis en kanonis groot invloed op die biegpraktyk en latere moraalteologiese outeurs uitgeoefen $^{84}$. Hy was aanvanklik dosent in kanonieke reg aan die Universiteite van Toulouse, Cahors, Salamanca en Coimbra, maar het later in Rome as pouslike bieguader opgetree. Sy kanoniekregtelike hoofwerk was die Consilia seu responsa in quinque

\footnotetext{
benadeelde se vermotnskade vergoed moet word. Hoewel nie-vermoeknskade nie vergoedbaar is nie, kan daar tog restitusie (by wyse van geld) geskied (dist. 15 art. 5 qu. 2, 2).

${ }^{78}$ Sententiae 4.15.3.9; kyk vn 44.

${ }^{7}$ In quartum Sententianum (Parys s.d.), dist. 15 quo. \$ 19 dubitatur, hy maak slegs melding van die vergoeding van vermoensklade.

${ }^{80}$ ad Secundam Secundae 62.1, ar.8.

${ }^{81}$ Afdeling 3 hierbo.

${ }^{82}$ ad Secundam Secundac 62.2, nr.9.

${ }^{83}$ ad Secundam Secundae 62.2, nr.9. Die benadeelde kan egter self die omvang van die vermoënskade bepaal.
}

${ }^{84}$ Vgl. oor Azpilcueta Reibstein, Althusius 32-34, asook Merzbacher, ZSS(KA): 77 (1960) 317.344, 318 e.v. en die literatuur deur hom vermeld op 318 n 6 . 
libros iuxta ordinem et titulos Decretalim distributa. In sy Directorium confessarii, Enchiridion sive manuale confessariorum et poenitentium, tree hy te voorskyn as beskrywer van by uitstek die kasuïstiese moraal 85 . Hy maak 'n onderskeid tussen satisfactio en restitutio; satisfactio is (na contritio en confessio) die derde deel van die sacramentum poenitentiae86; en dit moet naas restitutio plaasvind 87.

Daar bestaan ' $n$ restitusieplig vir die vergoeding van vermoënskade (damnum) wat voortgevloei het uit die aantasting van die liggaamlike integriteit. Die vermoënskade kan twee vorme hê: mediese uitgawes sowel as die verlies aan reeds gelede en toekomstige inkomste88. Die quantum word deur 'n bonus vir met inagneming van die aard van die skending, die tydstip, die plek, die hoedanighede van die betrokke persoon en ander relevante aangeleenthede bepaal ${ }^{89}$. Hy aanvaar as uitgangspunt dat daar geen vergoeding betaal kan word vir enige misvorming (deformitas) nie, omdat dit 'n skending van die lewensgoedere (bona vitae) inhou, en die bona vitae is as goedere van die hoër orde nie in geld waardeerbaar nie (bona altioris ordinis bona non aestimabilia) ${ }^{90}$. As gesag91 voer hy die Romeinsr egtelike stelreël homo liber nullo pretio aestimari potest ${ }^{92}$ en die stellings in die Digesta dat daar geen vergoeding vir enige deformitas in die geval van die verwonding van 'n vry man betaal mag word nie, aan 93 .

\footnotetext{
${ }^{85}$ Nufer, Spatscholastiker 7 meen: "In seinem umfangreichen Werk erweist er sich also einer der originellsten und fruchtbarsten Vertreters der Spanischen Schule seiner Jahrhunderts."

${ }^{86}$ Enchiridion sive manuale confessarionum et poenitentiam (1601) 3.1; 3.3.

${ }^{87}$ Enchiridion 3.2. Hy omskryf restitutio as 'n actus iustitiae commutativae (Enchiridion 3.2) Restitusie is geleē in die damni illati compensatio (Enchiridion 3.1); restitusic word deur die gelykheid (aequalitas) vereis (Enchiridion 17.27; 17.87).

${ }^{88}$ Enchiridion 15.22. Vgl. ook Fccnstra, La Responsabilité civile avamt Grotius $66 \mathrm{n} \mathrm{22.} \mathrm{Vgl}$ Enchiridion 15.26 (met verwysing na Clementina 5.4.1 en X 2.73.72) asook Enchiridion 17.90 \& nec obstat.

${ }^{89}$ Enchiridion 17.27 .

${ }^{90}$ Enchiridion 17.87. (met verwysing na D 48.19.10.2). Vgl. ook Enchiridion 17.88 asook Enchiridion $19.90 \$$ nec obstat; paragraaf secundo asook Enchiridion 17.91 \& novo.

${ }^{91}$ Enchindion 15.22

${ }^{22}$ Wat hy ook omskryf as: "homo suae vitae et salutis dominus non (est)" (Enchiridion 17.87). As gesag voer hy D 9.2.13 pr aan.
}

${ }^{93} \mathrm{D}$ 9.1.3; D 9.3.7; sien ook vn 94 
Azpilcueta wys dus die bestaan van 'n restitusieplig in foro conscientiae vir die vergoeding van immateriële skade (voortvloeiend uit die aantasting van die corpus) af; daar bestaan geen waarde vir die verlore fisiese integriteit (pretium deperditae integritatis) nie:

... qui percutit hominem liberum, tenetur ei restituere medicationis impensae, et stipendia ... deformitatem autem ex vulnere relictam nullatenus tenebitur compensare ${ }^{94}$.

Dominicus Soto (1494-1560) het sterk onder die invloed van Vitoria gestaan95. In 1532 word hy aangestel as hoogleraar in teologie aan die Universiteit van Salamanca, en verwerf reeds gedurende sy leeftyd wydverspreide roem ${ }^{96}$. In sy De iustitia et iure (1553) behandel hy bepaalde moraalfilosofiese aangeleenthede op so 'n wyse dat daar nie meer ' $n$ duidelike onderskeid is tussen moraalfilosofie en natuurlike privaatreg nie Sy De iustitia et iure word later een van die standaardwerke vir teoloë en juriste.

Soto onderskei ook tussen restitutio (as actus iustitiae commutativae) en satisfactio; restitusie is die teruggawe van verwyderde goedere, terwyl satisfactio (as pars poenitentiae) te make het met die herstel van 'n iniuria97. Satisfactio kry sodoende 'n element van boetedoening en is van toepassing op gevalle waar daar nie-vermoënskade ontstaan het ${ }^{98}$. Anders as Navarrus wat uitgaan van die standpunt dat satisfactio slegs deel is van die biegsakrament ${ }^{99}$, meen Sotus dat dit ook privaatregtelike implikasies het.

\footnotetext{
${ }^{94}$ Enchiridion: 15.22 . Vgl. ook Enchiridion 17.90 (met verwysing na $D$ 9.3.7 en D 9.1.3). Dit wil egter nie sé dat die benadeclde geen vorm van regsherstel gehad het nie; in bepaalde gevalle kon daar 'n condemnatio ralionis in die forum extemum gegee word: Enchiridion 28.212.

95 Die Dominikaner Soto was egter nie 'n student van Vitoria in Salamanea nie; veal eerder kan by as Mitbegnünder van die skool van Salamanca (naas Vitoria) gekenmerk word. Vgl. verder Reibstein, Alhusius 30 32-35; Krause Naturrechtler 35 e.v.; Welzel Naturliches Privatrecht und Spatscholastik, 243-250; Merzbacher, Moraltheologie 322; Otte, Vitoria 134 en die literatuur vermcld op 134 n 18); Nufer, Spatscholastiker, 6-7.

\%Die volgende spreuk het t.a.v. Soto (in sy lewe en daarna) gegeld: "Qui scit Sotum, scit totum" (hy wat Soto (se standpunte) ken, ken alles (die hele reg)).

${ }^{97}$ De iustitiae et iure (Anastatiese herdruk (1968) van die Salamanca 1556 uitgawe) 4.6.1. Hy wys dan op 'n verdere ses verskille tussen restitutio en satisfactio.

${ }^{98}$ gl. vn 86.

99Pauw, Persoonlikheidsknenking 62.
} 
Hy aanvaar dat by verwonding (net soos in die geval van doodslag) alle mediese uitgawes sowel as verlies aan inkomste in foro conscientiae vergoed moet word volgens die oordeel van wyse manne ${ }^{100}$.

Hy bespreek vervolgens die vraag of die Bybelse ${ }^{101}$ en kanoniekregtelike ${ }^{102}$ reêl dat slegs bogenoemde damna vergoed mag word ${ }^{103}$ nog geld ${ }^{104}$, en konkludeer dat waar daar 'n onherstelbare skending (mutilatio inrecuperabilis) is, daar 'n recompensatio moet plaasvind ${ }^{105}$. Dit kan slegs deur persone benede die adelstand (non illustres) geëis word.

Die recompensatio van die gelede iniuria stel satisfactio daar ${ }^{106}$. Dié nie-vermoënsregtelike (immateriële) nadeel word as ' $n$ iniuria aangemerk. Hy vermeld107 die standpunt van Duns Scotus ${ }^{108}$ dat die lex talionis - waar dit van regsweë voorgeskryf is - wel in foro exteriori toegepas moet word. Soto meen egter self dat daar eerder 'n satisfactio vir die gelede iniuria moet geskied ${ }^{109}$.

Diego de Covarruvias y Leyva (1512-1577) was 'n leerling van Vitoria en Soto in teologie en van Azpilcueta in kanonieke reg110. In 1533 word hy aangestel as professor in kanonieke reg aan die Universiteit van Salamanca. Hy verwys in sy werke na postGlossatore, tydgenootlike Franse Hervormers en Duitse skrywers soos Zasius. Hy het

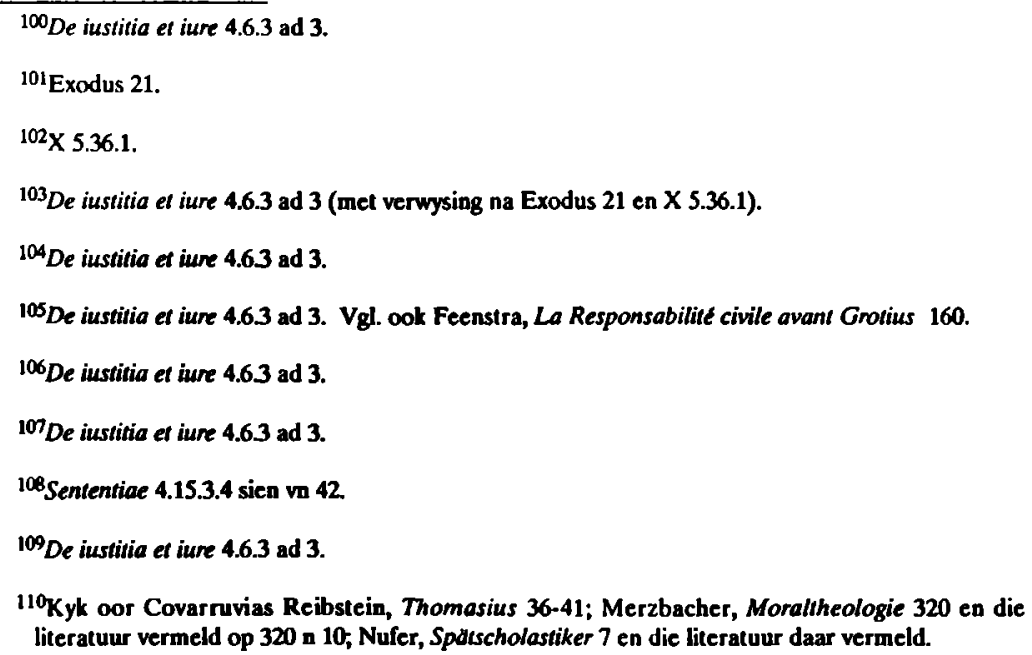


bekend gestaan as die Spaanse Bartolus 111 . Teen die einde van sy lewe word hy voorsitter van die Raad van Castilië. Sy belangrikste privaatregtelike werk was die Variae resolutiones wat in 1552 verskyn het.

Covarruvias stel laesio en restitutio teenoor mekaar; restitutio as actus iustitiae commutativae het te make met die kompensasie van vermoënskade deur tenggawe en gelykstelling (damni compensatio per redditionem et aequalitatem) ${ }^{112}$. In die geval van liggaamlike verwonding moet die waardebepaling van die nadeel (aestimatio damni) in foro conscientiae gerestitueer word ${ }^{113}$. Mediese onkostes sowel as verlies aan inkomste moet vergoed word ${ }^{114}$. Daar word egter geen aestimatio damni op grond van die misvorming van 'n vry mens (deformitas libri hominis) gemaak nie115. In navolging van Albericus de Rosate (ca. 1290-1360) - wat die siening van Jaques de Révigny $(+1296)^{116}$ volg ${ }^{117}$ - verklaar hy egter dat die reêl nie ten aansien van vrouens geld nie ${ }^{118}$. Behoudens dié uitsondering, huldig hy dus die standpunt dat daar geen vergoedingsplig vir 'n nie-vermoënskade voortvloeiend uit so 'n toegebragte iniuria is nie 119 .

\footnotetext{
${ }^{111}$ Reibstcin, Thomasius 40-41. Kohler, Archiv fär Rechts- und Wirtschaftsphilosophie 10 (1916/1917) 236 en 241 beskou hom as cen van die grootste Spaanse natuurregsgeleerdes en as die grootste juris. Vgl. Reibstein, Thomasius $41 \mathrm{en}$ Merbacher, Monaltheologie 320-321. Otte, Vitoria 134 sề t.a.v. Covarruvias: "...Covarruvias, der sich durch ausserordentliche Gelehrsamkeit nach Art der humanistischen Jurisprudenz hervortut ..."

${ }^{112}$ Opera omnia (1661) pars II relect. c.peccalum de reg. iur. in 6. initium; 6.7.1.

${ }^{113}$ Pars II relect. c. peccatum de reg. iur in 63.9.

${ }^{114}$ Vanae resolutiones 2.10 .7 quarto codem.

${ }^{115}$ Variae resolutiones 2.10 .7 (selfs nie waar daar sprake van gesigsontsiering is nie). As gesag voer hy D 9.1.3; D 9.3.7; Ludovicus Romanus Consilia et allegationes (1565) 278 en Abbas Antiquus Lectura aurea super quinque libris Decretalium (1210) ad X 5.36, nr. 1 aan.

${ }^{116} \mathrm{Na}$ die MS Leiden, Universiteitsbiblioteek Leiden, Collectio d'Ablaing 2, fol. 116 vo, verbeter aan die hand van die MS Napels, soos weergegee deur Feenstra-De Smidt, Geschiedenis van het Vermogensrecht, Tekstenboek (1978) $254 \mathrm{nr} .371$.

${ }^{117}$ Opera omnia (1585-1586) ad D 9.1 .3

${ }^{118}$ Variae resolutiones 2.10 .7 ; hy merk op dat die uitsondering ook t.o.v. slawe geld, maar dit is slegs 'n skynuitsondering aangesien 'n slaaf nie 'n liber homo is nie. Hy verwys die leser vir 'n uitgebreide bespreking t.a.v. die vergoeding van deformilas na Soto De iustitia et iure 4.6 .3 wat egter, soos aangedui, wel 'n vergoeding in foro conscientiae vir deformitas toegestaan.

${ }^{119}$ Dit wil egter nie sê dat die poena talionis in foro exteno uitgesluit is nie; selfs waar daar damna et expensae vergoed is, kan daar 'n accusatio by dic forum extemum aanhangig gemaak word.
} 
Die Spaanse Jesuilt Ludovicus Molina (1536-1600) het regsgeleerheid aan die Universiteit van Salamanca (vir een jaar) en teologie aan die Universiteite van Akala en Coimbra bestudeer. Daarna het hy hoogleraar aan die Universiteite van Evora (15681583), Coimbra en Salamanca geword ${ }^{120}$. Sy hoofwerk De iustitia et iure verskyn vanaf 1593 in ses bande, en is gebaseer op Thomas van Aquino se Summa Theologica. In hierdie monumentale werk verwys hy na Aristoteles, Thomas, die doctores Hispaniae, die Italiaanse Romaniste asook na die Spaanse en Romeinse reg, en bespreek hy talle privaatregtelike kwessies' ${ }^{121}$. Molina gaan uit van 'n regsorde in foro conscientiae ${ }^{122}$; hy poog om 'n selfstandige stel regsnorme daarvoor te ontwikkel.

Molina maak enersyds 'n onderskeid tussen restitusie 123 in wye sin ("die teruggawe van iets wat verskuldig is") en restitusie in eng sin ("die teruggawe of aanbod van iets ter goedmaking van iemand wat bedrieg of beseer/gekrenk is") ${ }^{124}$, en andersyds tussen laasgenoemde restitusie en satisfactio. Restitusie is gerig op die herstel in status quo ante ${ }^{125}$, terwyl satisfactio te make het met die recompensatio aequivalens (net soos in die geval van restitusie in eng $\sin )^{126}$ van 'n gelede iniuria ${ }^{127}$.

\footnotetext{
Waar daar bv. 'n siraf by wyse van die afkap van 'n hand of ander ledemaat (poena abscissionis manus alteriusve membri) kragtens wet voorgeskryf is, moet dit toegepas word Vgl. hieroor Variae Resolutiones 2.10.17; 2.9.1 en 2.10 .9$.

${ }^{12 n} \mathrm{Vgl}$. oor Molina Krause, Thomasius 44 e.v.; Thieme, Natüliches Privatrecht und Spdtscholastik 254 e.v asook Nufer, Spatrcholastiker 8 en die literaluur deur hulle vermeld.

${ }^{121}$ Thieme, Natilliches Privatrecht und Spdtscholastik, 255 merk op: ‘..Sodann Ludovicus Molina (1535-1600), der das Naturrecht mit dem Geiste seiner Zeit in stete verbindung zubringen weiss und uns zugleich über das Recht jener Periode die schalzenswertesten Auskünfte gibt; stets klas und skalastisch bestimmt, selbständigen Geistes, nie unter der Gewalt der Autoritaten erdruckt."

${ }^{122}$ Thieme, Natürliches Privatrecht und Spadtscholastik, 255 noem dit 'n "zweite, ubberst aatliche Rechisordnung".

${ }^{123}$ De iustitia et iure (Venesië 1609) 2.714pr.: Restitusie het veral (peculiariter) met bona extema te make; dit is noodsaaklik vir die sieleheil (salus) (2.716.1)

${ }^{124}$ Pauw, Persoonlikheidsknenking 62; De iustitia et iure 2.714 .2

${ }^{129}$ De iustitia et iune 2715.1.

${ }^{12 \hbar}$ De iustitio et iure 2.174.2.

${ }^{127}$ De iustitia et iune 2.715.2.
} 
In die geval van verwonding kan die benadeelde met die actio legis Aquiliae ${ }^{128}$ vir vermoënskade en met die actio iniuriarum (as daar opset teenwoordig was) vir die contumelia eis ${ }^{129}$. Die vermoënskade (resulterende uit die iniuria) omvat die mediese uitgawes sowel as die verlies aan reeds gelede en toekomstige inkomste, ${ }^{130}$ aangesien dit damna in rebus externis daarstel. Wanneer hierdie iniuria corporalis egter nie in vermoënskade resulteer nie, bestaan daar geen restitusieplig nie ${ }^{131}$. Restitusie moet by wyse van bona externa (soos veral deur middel van geld) plaasvind; compensatio by wyse van geestelike goedere (bonis spiritualibus) is onvoldoende ${ }^{132}$. Die berekening van die omvang van die vergoeding moet volgens die waardeoordeel van 'n wyse mens (prudens), met inagneming van die hoedanighede van die benadeelde, die aard van die verwonding en ander relevante faktore geskied 133 .

Sowel die aksie vir die vergoeding van vermoënskade as die actio ad vindictam iniuriae (die actio iniuriarum) kan of sivielregtelik (vir die betaling van 'n geldsom) of strafregtelik ingestel word. In laasgenoemde geval kom daar ook 'n sivielregtelike aksie aan die benadeelde toe om vir sy vermoënskade en vir die gelede iniuria (contumelia) restitusie te eis ${ }^{134}$ in dié mate waarin daar nog nie voldoende regsherstel met die actio criminalis was nie ${ }^{135}$

\footnotetext{
${ }^{128}$ De iustitia et iure 3.84.2.

${ }^{129}$ De iustitia et iure 3.40.1. Vgl. De iustitia et iure 3.19.1 waar Molina verskillende wyses van mutilatio noem. Hy wys ook daarop dat die talionis poena van die XII Tafels vervang is deur die betaling van 'n geldsom vir die gelede iniuria (3.40.4).

${ }^{130}$ De iustitia et iure 3.40 .1 kyk ook 3.87.1, 2,4 en 6 .

${ }^{131}$ De iustitia et iure 3.87.7, waar by drie gevalle noem. Die sienjing dat nobites dit as infro dignitatem behoort te beskou om vergoeding vir damna et expensae (vermoénskade) weens verwonding te ontvang, vertoon 'n sekere analogie met Soto (De iustitia et iure 4.6 .3 ad 3) se siening dat illustres geen eis mag instet vir 'n placatio lesi (nie-vermoénskade) nie. Die verpligting om damnum corporale (vermoënskade) te vergoed, verval waar dit slegs tydelik van aard is (De iustitia ef iure $3.883,5$ ), of waar voldoende resultaat reeds met 'n strafregtelike alksie (actio criminalis) behaal is (3.88.2).

${ }^{132}$ De iustitia et iure 3.84.7; 3.88.1.

${ }^{133}$ De iustitia et iure 3.88.1; 3.40.10.

${ }^{134}$ De iustitia et iure 3.40.10, 11, $19 ; 3.88 .2$.

${ }^{135}$ De iustitia et iure 3.40.19; 3.88.2.
} 
Hy wys 'n eis op grond van die wond, smart en ongerief as sodanig (vulnus dolor ac molestia) in foro conscientiae af; die dader word slegs gebonde gehou aan 'n strafbedrag (poena), as hy daartoe in foro exteriori veroordeel is ${ }^{136}$. Waar daar egter 'n gesigskending of ander misvorming daaruit voortvloei, is daar wel 'n restitusieplig in foro conscientiae ${ }^{137}$. Dit geskied in die geval van 'n vrou: haar dos moet vergroot word sodat sy net so 'n goeie huwelik kan sluit as voorheen (toe sy nog ongeskonde was) ${ }^{138}$. Molina meen dat dit ook uitgebrei moet word na mans ${ }^{139}$. Hy is dus van mening dat daar buite om die actio iniuriarum 'n nie-sivielregtelike, natuurregtelike ${ }^{140}$ eis in foro conscientiae vir corporale damnum deformitatis ac indecentiae ${ }^{141}$ die benadeelde toekom. Die voorwaardes vir die aksie is

- dat die immaterièle nadeel skatbaar is: hy gaan uit van die (fiktiewe) standpunt dat skoonheid en aansien van die menslike liggaam wel in geld waardeerbaar is ${ }^{142}$;

- die damnum corporis permanent moet wees, en

- die benadeelde die vergoeding wel wil ontvang (qui illud accepit compensari velit) ${ }^{143}$.

Waar daar egter geen permanente skatbare nadeel resulteer nie, is die dader slegs in foro exteriori vir vergoeding op grond van die iniuria (ad poenam propter iniuriam) aanspreeklik. ${ }^{144}$ Waar die iniuria egter ook neerkom op die aantasting van die gemeenskap

\footnotetext{
${ }^{136}$ De iustitia et iure $3.84 .4 ; 3.88 .3$.

${ }^{137}$ De iustitia et iure 3.84 .5 .

${ }^{138} \mathrm{Klaarblyklik}$ in navolging van Jacques de Révigny, ad D 9.1.3.

${ }^{139}$ De iustitia et iune 3.84 .5 .

${ }^{140} \mathrm{~V}_{\mathrm{g}}$. hier die analogiese gebruik van die sicut iure naturali in Disputatio 84.3 waar hy dic vergoeding van immateriele skade (soos toegestaan deur Thomas Secunda Secundae 62.2 ad primum - 3 hierbo) aksie in foro conscientiae bespreek; vgl. hieroor 3 hierbo en ook Pauw, Persoonlikheidskrenking 63

${ }^{141}$ De iustitia et iure 3.88. 4. T.a.v. die quantum-bepaling merk hy op dat die persoonlike eienskappe van die betrokkene (qualitas personae) deurslaggewend is.

${ }^{142}$ De iustitia et iure 3.88.5.

1433.88.5; vgl. die opmerking by vn 131 .

${ }^{144} \mathrm{Vgl}$. ook De institia et iure 3.88.3; 3.84.4.
} 
se opinie en waardering van die benadeelde (iniuria datum in honore ac existimatione), moet daar in foro conscientiae ' $n$ vergoeding plaasvind. ${ }^{145}$ Molina konkludeer ${ }^{146}$ dat in die geval van damnum immutationis vitae (die bovermelde skatbare misvorming ${ }^{147}$ ) en damna in honore ac existimatione ${ }^{\mathbf{1 4 8}}$ (wat resulteer uit die aantasting van die corpus), daar in foro conscientiae restitusie by wyse van 'n geldsom moet plaasvind 149 .

Die Suid-Nederlandse (Vlaamse) Jesurt Leonardus Lessius (1554-1623) ${ }^{150}$ het in Rome die voordragte oor die reg en geregtigheid van die Spaanse Jesuït Franciscus Suarez ${ }^{151}$ voor die Collegium Romanum gedurende die jare $1583-1584$ gevolg. Hy doseer aanvanklik filosofie aan die Jesuitekollege te Douai, en vanaf 1577 teologie te Leuven. In sy De iustitia et iure ceterisque virutibus cardinalibus (waarvan quaestiones 47-171 as kommentaar op Thomas se Secunda Secandae dien) wat in 1605 die eerste keer verskyn het ${ }^{152}$, verwys hy onder andere na die klassieke Romeinse juriste en die Spaanse natuurreggeleerdes. ${ }^{153}$ Lessius word beskou as die brug tussen die Spaanse natuurreggeleerdes en Hugo Grotius. 154

Lessius omskryf, net soos sy Spaanse voorgangers, restitutio as actus iustitiae commulativae ${ }^{155}$. Die verwonder (vulnerator) moet die aestimatio laboris (verlore

\footnotetext{
${ }^{145}$ De iustitia et iure 3.88.5.

${ }^{146}$ De iustitia et iure 3.886.

${ }^{147}$ De iustitia et iure 3.88.4.

${ }^{148}$ De iustitia et iure 3.88.5.

${ }^{149}$ Behalwe as die benadeelde genoẻ neem met bona allerius ordinis.

${ }^{150} \mathrm{Vgl}$. oor Lessius Krause, Thomasius 6476; Otte, Vitoria 136 en die literatuur vermeld op $136 \mathrm{n}$ 14; Nufer, Spätscholastiker 8-9 en die literatuur vermeld op 8 n 18.

${ }^{151}$ Suarez se leermeester was die Dominikaner Juan Manicio, self 'n student van Vitoria. Suarez staan bekend as die grootste teoloog en filosoof van die laat-Skolastick.

${ }^{152}$ Dic vyfde uitgawe - wat hy self versorg het - het reeds in 1621 verskyn - Nufer, Spatscholastiker 8.

${ }^{153}$ Nufer, Spditscholastiker 8-9. Krause, Naturrechtler 64-65 meen dat hy meer gereeld na die klassieke Romeinse juriste as na die teoloe en Spaanse natuurreggeleerdes verwys.

${ }^{154} \mathrm{Vgl}$. bywoorbeeld Nufer, Spalscholastiker 8.

${ }^{15 S}$ De iustitia et iure caeterisque virtutibus cardinalibus libri quatmor (Antwerp 1609) 2.7.4.15-16. Restitutio is ook noodsaaklik vir die sieleheil (solus): 2.7.10.
} 
inkomste) ${ }^{\mathbf{1 5 6}}$ sowel as alle ander damna pecuniaria (dus ook die mediese uitgawes) vergoed. ${ }^{157}$ Met verwysing na Azpilcueta, ${ }^{158}$ die glos op X 5.36.159, Covarruvias ${ }^{160}$ en Gomezius ${ }^{161}$ stel hy homself op die standpunt dat daar in die lig van die Digesta-reël soos vervat in D 9.1.3 en D 9.3.7 ${ }^{162}$ geen vergoeding vir enige deformitas is nie ${ }^{163}$ Hierdie verbod op die toekenning van immateriële skadevergoeding bestaan nie net in foro externo nie, maar ook in foro conscientiae ${ }^{164}$. Aangesien hier slegs van 'n iniuria (persoonlikheidskrenking) sprake is (en nie van damnum (skade) nie), kan daar slegs van satisfactio 165 by wyse van die uiterlike teken van berou en 'n versoek om vergifnis (en nie die betaling van 'n geldbedrag as satisfactio nie) sprake wees:

... pro damno aulem vilae, pro iniuria, solum deberi salisfaclionem quamdam, signis doloris et petitione veniae ...16t

\footnotetext{
${ }^{156}$ De institiae et iure 2.9.19.124-126

${ }^{197}$ De iustitio et iure 2.9.23.140 e.v.

${ }^{158}$ Enchiridion 15.22 sien n 123 supra
}

${ }^{159} \mathrm{D}$ i. Bernardus de Bolone Parmensis (+1226), die skepper van dic Glossa Ordinaria (Decretales Gregorii Pape IX (1584)) op die Liber Extra se glos op operas eius et impensas

${ }^{160}$ Variae resolutiones 2.10 .7 circa medium.

${ }^{161}$ Commentarionum varianumque resolutionum iuris civilis communis et regii tomi tres (1572) 3.6.12. Antonius Gomezius (1501-1562/1572) volg De Révigny en Albericus de Rosate se s1andpunt dat ontsiering in die geval van (ongetroude) vouens wel ageerbaar is. Gomezius was 'n Spaanse praktisyn en dosent, en is 'n verteenwoordiger van die sestiende-ceuse Mos llaticu (praklykreg). Latere Romeins-Hollandse skrywers verwys na dié standpunt van Gomezius as gesag vir die loekenning van 'n algemene aksie op grond van pyn en lyding.

162D 9.1.3: 'Cicatricium autem, aut deformisatis nulla fit aestimatio, quia liberum corpus nullam recipil aestimationem.

${ }^{163}$ De iustitio et iure 2.9.23.141.

${ }^{164}$ De iustitiace ef iure 2,9.23.142.

${ }^{169} \mathrm{Vgl}$. De iustitiae el iune 2.7.4.18 waar hy aanıonn dat satisfactio die vorm van regsherstel is in die geval van ' $n$ iniurio en restitutio in die geval van damna.

16h De iustitio et iure 29.23.145. Hy meen egter dat daar by die doodslag van 'n vry man wel 'n vergoedingsplig ex charitate (in teensielling tot ex iustitia - vgl. De iustitiae et iure 2.9.15.36; 2.7.15-16) ontstaan indien die erfgename behoefig is. Die Duitse moralfilosoof Petrus Binsfeld $(+1598)$ gee in sy belangrike Iraktaat oor iniuria en damnum datum (Commentarius in tituhum luris Canonici de iniurizi el damno dato (1598)) 'n uitgebreide bespreking van die vraag of damnum in corpore (bv. die verlies van 'n been) ook net soos damnum in bonis temporalibus (vermoënskade) vergoed moel word (1 q. 3). Hy verwys na die Middeleeuse Romeinse reg. 
Die standpunte van die moraalfilosowe kan soos volg saamgevat word:

* Dit is duidelik dat daar groot meningsverskille onder die moraalfilosowe en hul voorgangers ten aansien van die vraag of nie-vermoënskade vergoed moet word, bestaan het.

* Die outeurs wat 'n afwysende houding inneem (byvoorbeeld Azpilcueta en Lessius), steun op die Romeinsregtelike liberum corpus-reël en die glos op X 5.36.1. Ander skrywers soos Covarruvias staan (in navolging van Jaques de Révigny en Albericus de Rosate) vergoeding in geval van ontsierde vrouens toe; hulle beskou dit waarskynlik as 'n tipe damnum

* Die restitusieleer van Thomas van Aquino en die ius naturale het 'n groot invloed op daardie skrywers wat 'n algemene aanspraak erken (byvoorbeeld Vitoria, Molina en Soto), uitgeoefen.

* Ten aansien van die voorwaardes vir toekenning het Scotus die interessante vereiste gestel dat vergoeding veral in die geval van behoeftige persone gegee moet word, en slegs wanneer die benadeelde dit versoek. Soto wys weer daarop dat vergoeding vir immateriële nadeel nie deur belangrike persone (illustres) gevra (mag) word nie. Ten slotte wys Molina daarop dat immateriële skade slegs vergoed moet word as die benadeelde dit uitdruklik versoek; hy meen ook dat nobiles nie vermoënskade voortvloeiend uit ' $n$ verwonding behoort te ontvang nie.

\section{HUGO DE GROOT}

Soos reeds vermeld, het die Spaanse laat-Skolastici 'n groot invloed op Hugo de Groot (1583-1645) uitgeoefen. ${ }^{167}$ Dié beïnvloeding was direk sowel as indirek (byvoorbeeld

\footnotetext{
Azo, Dekretaliste (Honstiensis, Antonius de Butrio en Panormitanus) en moraalfilosowe (bv. onder andere Thomas, Scotus, Caietanus, Richardus de Mediaville, Hadrianus, Azpilcueta en Soto) (3 hierbo) asook na Henning Goden (Consilia 102.23-24) en Antonius Gomezius (Variae Resolutiones 3.6.12.). Binsfeld stel die Romeinsregtelike verbod, en verwys na die teenoorgestelde standpunt van Sotus (dat elke blywende verminking wel vergoed moet word) wat hy as in stryd met die geldende ius commune afmaak (Commentarius 1 qu. 3 concl. 5). Slegs in die geval van die ontsierde ongetroude vrou mag daar vergoeding toegestaan word. Vgl. verder t.a.v. Binsfeld Olivier, Pyn en lyding 108-109.

${ }^{167} \mathrm{Vgl}$. afdeling 2 hierbo.
} 
sy gebruikmaking van Lessius). ${ }^{168}$ Hierdie aanname word ondersteun deur die gedetailleerde kennis wat De Groot van die Spaanse laat-Skolastici gehad het, soos dit blyk uit die Prolegomena tot die De iure belli ac pacis. 169 In dié werk word daar ook talle verwysings na die Bybel, klassieke skrywers, die leges Longabardorum, die Romeinse reg, Middeleeuse teoloë (soos Thomas van Aquino en Caietanus), en die Spaanse laatSkolastici gevind. Sy restitusieleer is gebaseer op die van die Spaanse moraalfilosowe. ${ }^{170}$

Nadat hy in sy De iure belli ac pacis die geval van doodslag bespreek het en 'n eis vir mediese uitgawes sowel as 'n onderhoudseis vir diegene wat hy alere ex officio solebat. asook (met verwysing na die Romeinse reg) 'n eis op grond van die doodslag self van die hand gewys het (... vitae autem in libero homine aestimatio non fit ... $)^{171}$, bespreek hy in De iure belli ac pacis 2.17 .14 moontlike eise vir verwonding.

'n Eis op grond van ontsiering word met 'n beroep op die Romeinsregtelike liberum corpus-reël van die hand gewys. In die noot tot die laaste sin (sed sicut ... non fit) verwys hy na D 9.3.7 en Navarrus. Navarrus ${ }^{172}$ (die Spaanse laat-Skolastikus Martinus Azpilcueta) wys, soos aangedui, in sy Enchiridion sive manuale confessariorum 173 ('n bieghandleiding) 'n eis op grond van ontsiering af. Dit is verder waarskynlik dat De Groot in hierdie verband sonder uitdruklike vermelding op Lessius (wat, soos hierbo aangedui, 'n minderheidstandpunt inneem) steun. ${ }^{174}$ In die voorafgaande gedeelte oor doodslag in De iure belli ac pacis (2.17.13) het hy direk na Lessius ${ }^{175}$ as gesag verwys.

\footnotetext{
${ }^{168}$ Molhuysen, De bibliotheek van Hugo de Groor 62. Sy biblioteek hel in 1618 bywoorbeeld Soto se De iustitia et iure bevat.

${ }^{169}$ De iure belli ac pacis Prolegomena 37, 38, 52 en 55.

${ }^{170} \mathrm{Vgl}$. bv. die verwysings vermeld in De iure belli ac pacis 2.17 .

1712.17 .13 .

$177_{K}$ yk afdeling 5 hierbo.

173 Enchiridion 15.22.

${ }^{174}$ De iustitiae ef iune 2.9.23.141 (5 hicrbo).

${ }^{175}$ De iure belli ac pacis 2.17.13; vgl. ook Feenstra, La Responsibilite civile avant Grotius 158 e.v. Vgl. egter die standpunt van Pauw, Persoonlikheidskrenking 70-71 wat meen dat De Groot die vraag na vergoeding van pyn, lyding en ontsiering hier oopgelaat het. In die lig van die aangevoerde argumente kan daar egter nie met Pauw saamgestem word nie; so cok Feenstra 1972 Acta Juridica 227, 235 en Nufer, Spatscholastiker, 73.
} 
In sy Inleydinge tot de Hollandsche Rechts-geleerdheid (wat hy tydens sy gevangenisskap in Loevenstein geskryf het en wat eers in 1631 gepubliseer is) beweeg hy soos die Spaanse moraalfilosowe weg van die bekende aksies, en klassifiseer hy onregmatige dade (wat hy misdaad noem) aan die hand van die belange wat aangetas word:

Dadelijke misdaad zal bekwamelyk afgescheiden worden naar de verscheidenheid van de zaken die byzondere lieden toekomen: die wy voor dezen hebben gezegd te zyn 't leven: 't lichaem; de vrijheid; de eer; en goederen. ${ }^{176}$

In die gedeelte van misdaad tegen 't lichaem omskryf hy so 'n misdaad as die afslaan verminking, veroorsaking van bloeding of 'n ander krenking van 'n liggaamsdeel; vermoënskade (verlies van huidige en toekomstige inkomste en mediese uitgawes) moet vergoed word; 177 bowendien moet daar 'n bedrag vir smart en ontsiering ${ }^{178}$ betaal word:

De smert en ontciering van 't lichaem, hoewel eigentlyk niet zynde vergoedelyk, worden op geld geschat, 200 wanneer zulks verzocht word. ${ }^{17}$

Hy beskryf dus hier die aksie vir pyn, lyding en ontsiering. Die ooreenkomste in sy formulering van die aksie weens pyn en lyding met dié van die Spaanse laat-Skolastici ten aansien van verskeie aangeleenthede is duidelik. Soos hulle baseer hy dit ook op die algemene restitusieplig (wederevening der onevenheid). ${ }^{180}$ Net soos Thomas van

\footnotetext{
${ }^{176}$ Inleydinge 3.33.1.

171'Inleydinge 3.34.1-2: "... Hieruit ontstaat verbintenisse tot vergoeding van 't meestersloon, schade en winstverzuim, 't zy gedurende de genezing. 't zy ook daarna, 200 wanneer het gebrek is gedurig ..."

${ }^{178}$ Oor die gebruik van die terminologie merk Feenstra 1958 Acta Juridica 27,41 n 70 op: "De 'onteiering van 't lichaem' wijst reeds op geleerde invloed; in het inheemse recht zal dese naast de 'smert', niet genoemd zijn."

${ }^{179}$ Inleydinge 3.34.2. In die Rechtsgeleerde Observatien 3.99 word die teks met verwysing na artike 65.5 die Keuren van Putten (1587) en artikel 11.23 van Keunen van Amsterdom (1656)

bevestig.

${ }^{180}$ Afdeling 3 hierbo. Vgl. ook Inleydinge 3.32 .7 waar by aandui dat daar uit elke misdaad twee verbintenisse ontstaan: "... de cene tot straf; de andere tot wederevening van de onevenheid." Waar die openbare straf voorheen deur die individu uitgeoefen is, moet dit nou van staatswee geskied; maar die skuld tot wederevening der onevenheid (die basiese restitusieplig) is gebaseer op die aangebore reg (natuurreg), hoewel dit nader omskryf word in die burgerlike wet. Vgl. verder Inleydinge 2.32.9.
} 
Aquino181 en die Spaanse laat-Skolastici 182 wys hy daarop dat restitutio in specie nie kan plaasvind nie - (vergelyk hoewel eigentlyk niet zynde vergoedelyk) - daar moet dus 'n soort ekwivalente restitusie plaasvind. 183

Die zoo wanneer zulks versocht word slaan enersyds op die standpunt van sommige Spaanse laat-Skolastici dat slegs non illustres dit mag eis en dat dit slegs toegestaan word waar dit uitdruklik geëis word, en andersyds op die feit dat dit hier om iets gaan wat eintlik nie vergoedbaar is nie. 'n Ander verdere verklaring vir die laaste sinsnede is dat net soos enige ander geding, die regter nie vanself ' $n$ toekenning sal maak nie.

Samevattend kan daar dus gesê word dat De Groot die aksie weens pyn en lyding in sy formulering in Inleydinge $\mathbf{3 . 3 4} .2$ binne die raamwerk van die restitusieleer van Thomas en die latere Spaanse moraalfilosowe (wat hy, soos aangetoon, oorgeneem het) verklaar. ${ }^{184}$ In die Inleydinge staan hy sodanige aanspreeklikheid toe, maar in sy De iure belli ac pacis wys hy dit geheel en al van die hand. 185

\footnotetext{
${ }^{181} \mathrm{Vgi}$ afdeling 3 hierbo

${ }^{182} \mathrm{Vgl}$ afdeling 5 hierbo

${ }^{183}$ Volgens Feenstra 1958 Acta Juridica 27 openbaar De Groot in hierdie frase 'n bepaalde terughoudendheid in die toekenning van vergoeding vir smart en ontsiering: "Vergoeding voor 'smert' en ontsiering is een concessie aan de pracktijk van zijn tijd, die door De Gropl eigentlijk wordt afgekeurd." 'n Kritiese evaluering van die standpunte van die Spaanse moraalfilosowe (afdeling 5 hierbo) laat egter duidelik blyk dat dieselfde "terughoudendheid" m.b.t. nobiles en die in beginsel onvergoedbaarheid van sodanige immateriële nadeel ook by hulle bestaan. Daar kan dus nie gese word dat De Groot se terughoudenheid op praktykoorwegings berus nie; sy formulering (ook in hierdie verband) volg dié van die Spaanse mcraalfilosowe bykans woordeliks na.

${ }^{184} \mathrm{Vgl}$ afdeling 3 hierbo.

${ }^{185} \mathrm{Vgl}$. verder die dictum van Feenstra aangehaal in vn 183 . In Inleydinge 3.34 .5 bespreek hy die geval van opsetlike verwonding en deel mee dat daar op bepaalde plekke voorskrifte vir die betaling van geldboetes is; dit dien tot versoening van die benadeelde, en word bo die voorzegde vergoeding (vermoënskade en vergoeding vir sment en ontsiering) gegee. Dit slaan waarskynlik op die gewoonteregtelike boetesisteem wat nog op bepaalde plekke gegeld het. Andersyds dien dit as stawing vir die siening dat $D e$ Groot nie opset as skuldvorm vir aanspreeklikheid op grond van smen en ontsiering vereis het nie. Kyk ook Consultatien, Advysen en Advenissementen 3168 waar De Groot meedeel dat soengeld in die geval van doodslag nog steeds betaal mocs word Kyk verder Inleydinge 3.34.9 waar De Groot verwys na die Keuren van Voorn waarkragtens die benadeelde moes gaan verslag doen het van sy smer; vgl. ook Rechtsgeleerde Observatien 3.97 Laasgenoemde twee gevalle vloei voort uit die gewoonteregtelike voorskrifte met betrekking tot verwonding.
} 


\section{SAMEVATTING}

Anders as wat die Suid-Afrikaanse regspraak en sommige outeurs meen, laat bogenoemde uiteensetting duidelik blyk dat die moraalfilosofiese uitgangspunte van Thomas van Aquino (met sy oorname van Aristoteles se geregtigheidsleer) 'n wesenlike rol in die erkenning van aanspreeklikheid vir immateriële nadeel voortvloeiend uit die aantasting van die fisies-psigiese integriteit gespeel het. Sy algemene benadering is nagevolg in die laat-Middeleeuse biegpraktyk wat vereis het dat elke lidmaat jaarliks moes bieg; in dié hof van die gewete (forum conscientiae, forum internum) is die betrokke lidmaat verplig om sowel vermoënskade as immateriële nadeel wat hy veroorsaak het, te vergoed. Die restitusie is as noodsaaklik vir die sieleheil beskou; daarsonder kon lidmate die voorreg van 'n Christelike begrafnis ontsê word.

Die meerderheid van die sestiende-eeuse Spaanse moraalfilosowe het die erkenning van die aksie verder gevoer deur enersyds aansluiting te vind by Jaques de Révigny se uitsondering op die Romeinsregtelike verbod op die vergoeding van sodanige persoonlikheidsnadeel (hulle het sy uitsondering met betrekking tot ongetroude vrouens uitgebrei na alle gevalle van sodanige nadeel). Andersyds was die grondslag steeds die verpligting tot restitusie as actus iustitiae commutativae hoewel restitusie van die saak self (die geskende liggaam) nie kon geskied nie, moes 'n gelykwaardige vergoeding as satisfactio (laesio) in geld aan die benadeelde betaal word. In teenstelling tot die bieghandleidings was hulle werke daarop gerig om ' $n$ alternatiewe openbare regsorde gebaseer op geregtigheid daar te stel. Naas die erkenning van aanspreeklikheid weens uiterlike skending (deformitas, cicatrix), is daar ook voorsiening vir innerlike smart (dolor) gemaak. Slegs mense wat nie aan die hoè stand behoort het nie (non illustres) kon die aksie instel; bowendien moes dit uitdruklik geèis word, en kon die regter dit nie mero motu toestaan nie.

Die belangrike Romeins-Hollandse juris, Hugo de Groot , het die Spaanse moraalfilosowe as 'n belangrike bron beskou. Alhoewel hy in sy volkeregtelike werk, De iure belli ac pacis, sodanige aanspreeklikheid afwys, erken hy dit wel in sy Inleydinge tot de Hollandsche Rechts-geleertheid waar hy aanspreeklikheid vir die vergoeding van sodanige persoonlikheidsnadeel op die algemene plig tot wederevening der onevenheid (restitusie) baseer. Dieselfde beperkings met betrekking tot die uitsluiting van nobiles en die toestaan van 'n gepaste bedrag slegs as dit uitdruklik geëis word, kom ook by De Groot voor. Sy standpunte is deur latere Romeins-Hollandse outeurs oorgeneem, en vorm sodoende deel van die huidige Suid-Afrikaanse reg. 
Die effek van De Groot (en later outeurs) se erkenning van aanspreeklikheid vir persoonlikheidsnadeel voortvloeiend uit die aantasting van die fisies-psigiese integriteit as 'n afsonderlike regsaanspraak (naas die geykte hoof deliktuele aksies) hou vir die deliktereg belangrike konsekwensies in. Dit behels die noodsaak vir duidelike begripsonderskeiding met betrekking tot die doel van die aksie weens pyn en lyding (vergoeding van persoonlikheidsnadeel), die aanwendingsgebied (aantasting van die corpus), die teoretiese grondslag (herstel van onreg - wederevening der onevenheid of restitusie) asook die berekening van die quantum (die bepaling van die Wet op die Verdeling van Skadevergoeding 34 van 1956 waarvolgens die relatiewe nalatigheid van die benadeelde (indien nie die eiser nie) in die geval van vermoënskade wel in ag geneem word, is nie by pyn en lyding direk ter sake nie). Die berekening van die omvang van genoegdoening weens persoonlikheidsnadeel voortvloeiend uit pyn en lyding, is voorts ook nie objektief kwantifiseerbaar nie - dit word, soos reeds deur Thomas gestel, aan die regspreker oorgelaat.

\section{BIBLIOGRAFIE}

ANDREAE, J. 1581. In quintum Decretalium librum novella commenatria. Venesië. ANTIQUUS, A. 1210. Lectura aurea super quinque libris Decretalium. Tricr.

AZPILCUETA, M. 1601. Enchiridion sive manuale confessariorum et poenitentiam. Antwerp.

BERGFELD, C. 1977. Katholische Moraltheologie und Naturrechtslehre. (In Coing, H., red. Handbuch der Quellen und Literatur der neueren Privatrechtsgeschichte. Munchen : Beck. Il/1, p. 999 1034 999-1015.)

BINSFELD, P. 1598. Commentarius in titulum Iuris Canonici de iniuriis et damno dato. Trier.

BOBERG, P.Q.R. 1985. Law of Delict. Kaapstad : Juta.

COVARRUVIAS, D. 1661. Variae resolutiones, Opera omnia. Lyon.

DE BOTONE PARMENSIS, B. 1470. Casus Longi (cum notabilibus) super quinque libros Decretaltium. Basel.

DE CLAVASIO, A.C. 1513. Summa Angelica de casibus conscientiae. Trier.

DE GROOT, H. 1754. Consultatien, Advysen en Advertissementen. Utrecht/Amsterdam.

DE GROOT, H. 1778. Rechtsgeleerde Observatien. 's Gravenhage.

DE GROOT, H. 1939. De iure belli ac pacis. Leiden : De Kanter-Van Hettinga Tromp.

DE GROOT, H. 1965. Inleydinge tot de Hollandsche Rechts-geleerdheid. Leiden : Dovring-FischerMeijers.

DE MEDIA VILLA, R. 1478. Super quarto libro Sententiarum. Venesië.

DE PRIERIO, S. 1528. Summa Summarum casuum conscientiae seu Silvestrina. Lyon.

DE REVIGNY, J. 1585/1586. Opera omnia. Venesië.

DURANTI, G. 1539. Speculum Iudiciale. Lugduni.

FEENSTRA, R. 1958. Over de corsprong van twee omstreden paragrafen uit de Inleidinge van Hugo de Groot (III.33.2 en III.34.2). Acta Jundica, 27:41 n 70.

FEENSTRA, R. 1959. Thêories sur la responsabilité civile en cas d'homicide et en cas de lésion corporelle avant Grotius en droit prive. (In Feenstra red. Etudes d'histoire du droit privé offertes á Pierre Petot, 157-171.) 
FEENSTRA, R. 1972. Historical development of delictual liability for killing and for the infliction of bodily harm. Acta Juridica, 227-235.

FEENSTRA, R. 1972/1973. L'Influence de La Scholastique espagnol sur Grotius en droit prive: quelques experiences dans des questions de fond et de forme, concernant notamment les doctrines de l'erreur et de l'enrichissement sans cause. (In Feenstra red. La Seconda Scolastica nella formazione del diritto moderno, Incontro di studio, Firenze, 16-19 ottobre 1972, Atti, Milaan.)

FEENSTRA, R, 1974, Fata luris Romani. Leiden.

FEENSTRA, R. en de SMIDT, J. 1978. Geschiedenis van het Vermogensrecht, Tekstenboek. Deventer: Kluwer.

GLORIEUX, S. Dictionnaire de Theologie Catholique XIV 2 col. 2350.

GODEN, H. 1563. Consilia Caleberrimi. Budissinae.

GOMEZIUS, A. 1572. Commentariorum variarumque resolutionum iuris civilis communis et regii tomi tres. Venesie.

HADRIANUS, 1518. Quaestiones in quartum Sententiarum praesertim circa sacramenta. Parys.

KOHLER, W. 1916/1917. Die spanischen Naturrechtslehrer. Archiv für Rechts- und Wirschafsphilosophie, 10:236-241.

KRAUSE, O.W. 1949. Naturrechtler des sechzehnten Jahrhunderts. Gottingen, Diss.

LE BRAS, G. 1960. Pentitentiels, Dictionnaire de Theologie Catholique. XII 1 col. 1160.

LESSIUS, L. 1609. De iustitia et iure ceterisque virtutibus cardinalibus libri quattuor. Antwerp.

MAUSBACH, J. \& ERMECKE, G. 1959. Katholische Moraltheologie. Munster : Beck.

MERZBACHER, F. 1960. Azpilcueta und Covarruvias. ZSS $(K A)$, 77:317-344.

MICHAUND-QUANTIN, P. 1962. Somme de casuistique et manuels de confession au moyen áge. (XIIXVI siecles). Leuven.

MOLHUYSEN, P. 1943. De bibliotheek van Hugo de Groot. Amsterdam.

MOLINA, L. 1609. De iustitia et iure. Venesië.

NÖRR, KW. 1973. Die kanonistiese Literatur. (In Coing, H., Handbuch der Quellen und Literatur der neueren Privatrechtsgeschichte. München : Beck. I/11 365.)

NUFER, G. 1969. Über die Restitutionslehre der spanischen Spatscholastiker und ihre Ausstralung auf die Folgezeit. Freiburg., Diss.

OLIVIER, N.J.J. 1978. Die aksie weens die nalatige veroorsaking van pyn en lyding. Leiden., Diss.

OTTE, G. 1964. Das Privatrecht bei Francisco de Vitoria. Köln/Graz : Beck.

PAUW, P.C. 1976. Persoonlikheiskrenking en skuld in die Suid-Afrikaanse reg. Leiden : Diss.

REIBSTEIN, E. 1955. Joharnes Althusius als Fortsetzer der Schule von Salamanca. Karlsruhe.

ROMANUS, L. 1565. Consilia et allegationes. Lyon.

SCHILLING, O. 1923. Die Staats- und Soziallehre des HI. Thomas von Aquin. Paderborn.

SCOTT, TJ. 1976. Die geskiedenis van die oorerflikheid van aksies op grond van onregmatige daad in die Suid-Afrikaanse reg. Leiden : Diss.

SCOTUS, J.D. 1539. Questiones in librum quartum Sententiarum, Opera Omnia. Lyon.

SOTO, D. 1556/1968. De iustitia et iure libri decem. Madrid.

THIEME, H. 1953. Naturliches Privatrecht und Spátscholastik. ZSS (GA),70:230-262.

THIEME, H. 1946. Das Naturrecht und die europäische Privatrechtsgeschichte. Basel : Rupert.

TRUSEN, W. 1962. Anfänge des gelehrten Rechts in Deutschland - Ein Beitrag zur Geschichte der Fruhrezeption. Wiesbaden.

TRUSEN, W. 1971. Forum internum und gelehrtes Recht im Spätmittelalter. ZSS $(K A)$ 88:83-126.

TRUSEN, W. 1973. Die gelehrte Gerichtsbarkeit der Kirche. (In Coing, H., red. Handbuch der Quellen und der Literatur der neueren europăischen Privatrechtsgeschichte. München : Beck. I 486.)

VAN AOUINO, T. 1897. Opera Omnia, vol. 9: Secunda Secundae Summa Theologica. Rome. 


\section{Moraalfilosofiese grondslae van die aksie vir pyn en lyding}

VAN AQUINO, T. 1953. Summa Theologica. Heidelberg : Rupert.

VAN DER MERWE, NJ. en OLIVIER, PJJ. 1989. Die onregmatige daad in die Suid-Afrikaanse reg. Pretoria : Van der Walt.

VAN DER WALT, J.C. 1979. Delict. Durban : Butterworths.

VAN ZYL, D.H. 1983. Geskiedenis van die Romeins-Hollandse Reg. Durban : Butterworths.

VILLEY, M. 1966. La Formation de la Pensé juridique moderne. Parys : Giscard.

VITORIA, F. 1934. De Summa Theologica, de iustitia et iure. Madrid : Beltram de Heredia.

WELZEL, H. 1962. Naturrecht und materielle Gerechtigkeit. Gottingen : Rupert

WIEACKER, F. 1967. Privatrechtsgeschichte der Neuzeit. Gottingen : Rupert.

HOFSAKE

Hoffa v SA Mutual and Fire Insurance 19652 SA 944 (K)

Bester v Commercial Union Versekerinosmantskanoy 19731 SA 769 (A)

WETGEWING

Wet on die Verdeling van Skadeverroceding 34 van 1956 